\title{
DIE WERKING VAN DIE QUADRICEPS-SPIER en 'n FUNKSIONALE BENADERING TOTSY HEROPLEIDING
}

(Miss) L. M. DAVIDS/SENIOR LECTURER: TRAINING

B.Sc. (Physio) Rand., B.A. Hons. (U.O.F.S.), Dip.Ed. Physiother. Pret.

Disfunksie van die Quadriceps-spier is een van die mees algemene verskynsels in trauma van die onderste ledemaat. Enige besering in die omgewing van die kniegewrig sal 'n vermindering in die effektiewe werking van hierdie spiergroep veroorsaak en 'n erger graad van besering en/of chirurgie kan 'n totale inhibisie veroorsaak. Dit is veral in laasgenoemde geval dat die pasient na Fisioterapie verwys word vir 'Quadriceps dril'. Die sukses of mislukking van hierdie 'dril' hang af van 'n goeie begrip van die werking van dié spieroroep. Anatomies word die quadriceps beskou as 'n knie zstensor-d.w.s. met die voet vry word die knie van die gebuigde posisie tot die reguit posisie gebring. Dit is natuurlik die aksie van hierdie spier, maar waarom moet die spierbou so massief wees vir so 'n ligte werk? Ekstensie van die knie met 'n vry voet is nie die primêre funksie van die quadriceps nie.

Let us first consider its structure. The quadriceps is an extremely bulky muscle which covers the whole of the front of the thigh. Morphologically it can be divided into four distinct components:-

(i) Rectus Femoris which is fusiform in shape, arises from the anterior inferior iliac spine and inserts into the base of the patella. It forms the superficial central part of the quadriceps tendon. Rectus femoris is a two-joint muscle i.e. it acts on both the hip and the knee joints.

(ii) Vastus lateralis is the largest component of quadriceps femoris. It arises from the intertrochanteric line, the. anterior and inferior borders of the greater trochanter and the upper half of the lateral lip of the linea aspera. It inserts principally into the lateral border of the patella and into the quadriceps femoris tendon.

(iii) Vastus medialis arises from the lower part of the intertrochanteric line, spiral line, medial lip of the linea aspera and upper part of the medial supracondylar line etc. Its fibres pass downward and forward and are chiefly attached to the medial border of the patella and the quadriceps tendon. The lowest fibres are almost horizontal and form the bulge on the medial side of the knee that is distinctive in a well-developed muscle. The fibres of vastus medialis run thus in two distinct directions and one would expect the function of the two parts to differ.

(iv) Vastus intermedius arises from the anterior and lateral surfaces of the upper two thirds of the shaft of the femur. In its upper part it is frequently fixed with the upper fibres of vastus medialis. Its insertion forms the deep part of the quadriceps tendon and it is also attached to the lateral border of the patella. (11)

During the last ten years a fair amount of work has been done on the action of the individual parts of the the quadriceps. In a mechanical study using amputation specimens, Lieb and Perry (17) established that:-

(a) Vastus intermedius is the most efficient extensor. With various combinations the total force combination was very close to that of vastus intermedius alone. Vastus medialis alone could not extend the knee.

(b) Full knee extension and terminal rotation were attained only when the primary extensor was vastus lateralis. The horizontal fibres of vastus medialis failed to produce extension. Full extension was obtained when the extension load was on any of the other long heads. (c) When a weight was applied to the horizontal fibres of vastus medialis sufficient to keep the patella centred in the femoral groove, the force required for the vastus lateralis to extend the knee fully, was decreased by $13 \%$.

(d) As the knee became progressively straighter, a greater force was required.

They came to the conclusion that:-

(i) The only selective function attributable to the horizontal fibres of vastus medialis is patellar alignment.

(ii) The extensor lag accompanying knee lesions is a function of the loss in mechanical advantage of the quadriceps during the last $15^{\circ}$ of extension, a 60 per cent increase in force being necessary to complete extension.

(iii) The clinical prominence of vastus medialis is related to the marked obliquity of its distal fibres, the lowness of its insertion and the thinness of the fascial covering of this part of the muscle.

(iv) Early atrophy of the vastus medialis and lack of terminal extension after injury are indicative of general quadriceps weakness.

These findings are borne out by other investigators performing electromyographic studies on both normal and recently injured knee joints. $(4,15,18,24)$ One is able to infer from available studies that no individual component of the quadriceps performs consistently in any specific part of the range. The muscle components act as a whole with considerable variation. There is consensus of opinion that the action of the horizontal fibres of vastus medialis during the terminal phase of extension, is to retain patella in its groove on the patellar surface of the femur, helping to counteract the natural tendency to lateral displacement. $(11,26)$

All these studies have been performed with the quadriceps acting as a knee extensor with the foot free. Insofar as they establish the necessity to re-educate the muscle as a whole and not to concentrate on one component alone viz vastus medialis, they can assist in the planning of a rehabilitation program. However, in order to obtain the optimum performance in the minimum time, one must consider the function of the quadriceps in the living body.

The quadriceps is a postural muscle which fact is the reason for its bulk. Its function is to counteract gravity in a multitude of different postures. Its function is not so much to maintain a standing posture as to perform the powerful movements required for the changes of posture such as sitting to standing, crouching to standing, etc. (3) In the erect position the line of gravity falls slightly in front of the knee joint so that quadriceps action is slight, if not entirely absent. According to Basmajian (3) during walking on the level, the quadriceps contracts as extension of the knee is being completed, early extension being principally passive (this principle is used in the construction of the free knee joint in an above-knee prosthesis), and it continues to act during the early part of the supporting phase while the line of gravity is behind the knee joint. A strong quadriceps is thus not a requirement for walking on the level. Patients with a paralysed quadriceps use their hand to lock the knee at the heel strike, and otherwise manage very well.

Thus, as soon as the line of gravity falls behind the knee and if there is any degree of flexion, the quadriceps will be 


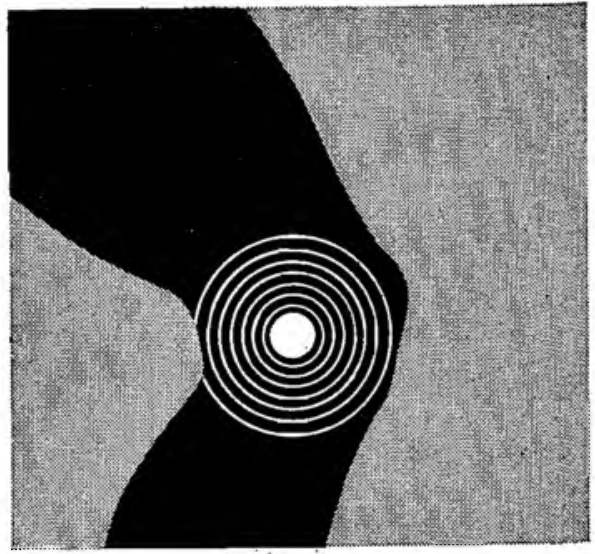

1. Rheumatic pains in joints and muscles

3. Muscle cramips and stiffness

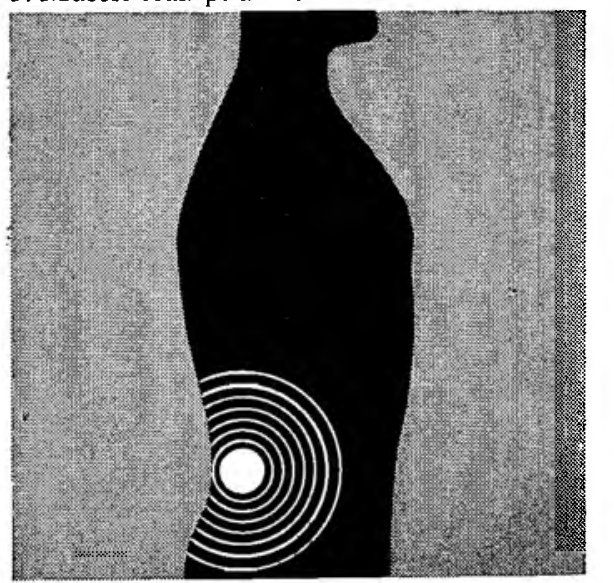

pain is our scene...

\section{Fibrositis}

4. Other local pains and aches

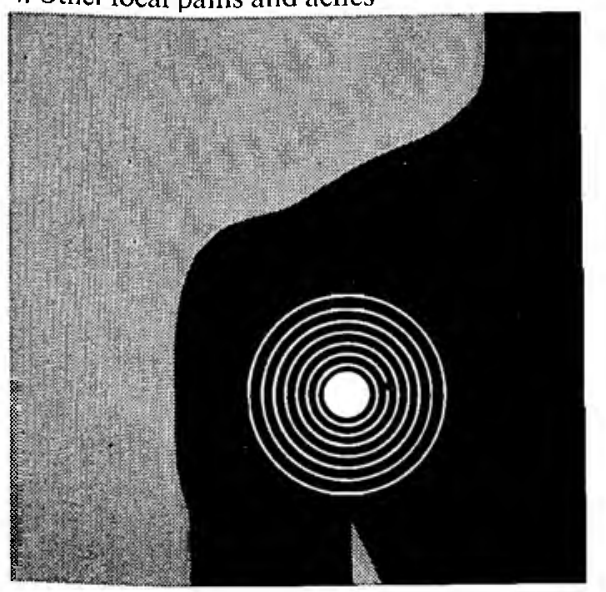

Formula:

Diethylamine

Salicylate $10 \mathrm{~g}$

Nopoxamine $1 \mathrm{~g}$

Excipient q.s.ad. $100 \mathrm{~g}$

\section{analgen ointment}

Formulation: Two pain-killing ingredients, diethylamine salicylate and nopoxamine, in a special ointment base to speed subcutaneous penetration.

Indications: Rheumatic pains in joints and muscles, low backache, fibrositis, sprains and bruises, muscular cramps and stiffness, neuralgic pains.

Action: Soothing, deep-penetrating. rapid pain relief with local anaesthetic effect.

Application: Massage gently into the skin around the affected area until completely absorbed. Apply as often as required.

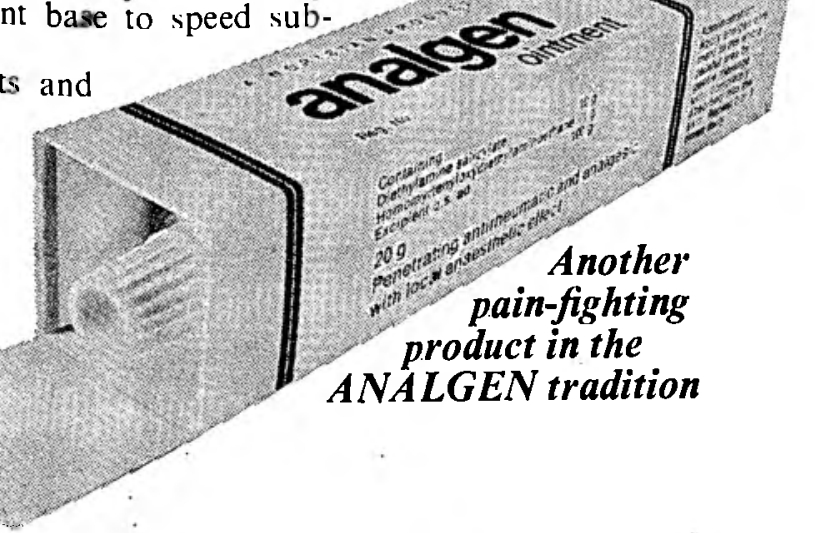


thrown into action. In walking up and down an incline the muscle works more strongly than on a level surface. Walking up and down steps is impossible without an adequately functioning quadriceps on the supporting leg-the higher the step the greater the muscle activity. The major action of this muscle is, therefore, to straighten the knee with the foot fixed on the ground i.e. to help support the body weight, or to allow the knee to bend (by means of a lengthening reaction), again with a fixed foot. In this fashion it performs its postural function and it is in order to support the weight of the body that the quadriceps is so massive in structure.

The re-education of quadriceps function poses several problems:-

(I) After injury or surgery there is a reflex inhibition which is thought to be a result of pain. In the studies performed on knee injuries, most investigators come to the conclusion that the inhibition is central and that pain and not soft tissue stretching is the major factor concerned. $(8,9,13,22,23,27,28,30)$

(2) With most patients who have undergone knee surgery, flexion of the knee is not allowed for approximately 10 days to avoid the possibility of a haemarthrosis. In fact the knee joint is generally splinted in full extension.

(3) Immediate weight-bearing is not usually permitted.

(4) The last being most important from the point of view of re-education - the principle function of the quadriceps is not to lift the leg up straight and this combined with the previously mentioned factors, impedes re-education.

It must be understood that re-education or therapy does not comprise the motor act alone. Normal motor activity is always a response to stimuli and therapy should therefore consist of the application of stimuli to activate the motor response in such a way as to stimulate normal motor functions.

According to Prof. Rood (29) motor development takes place in four steps; -

(i) In a non-weight-bearing reciprocal pattern moving the small lever e.g. the foot in a mass flexion pattern. This is seen in the supine infant kicking.

(ii) In a weight-bearing co-contraction pattern e.g. in the stabilizing action seen in stance patterns i.e. all muscle groups around a joint are active.

(iii) In a weight-bearing pattern moving the larger lever e.g. in the action of bringing the body over the foot the calf muscles are thrown into strong contraction.

(iv) In a co-ordinate pattern e.g. at the heel strike phase of walking there is dorsiflexion of the foot with knee extension and hip flexion.

These patterns of movement are presented in order of Complexity and are found to occur in this order during the developmental process. If functions such as stabilizing are lost as a result of reflex inhibition they must be restored before progressing to the more complex skills.

Rood also classifies muscles into two major functional groups viz. mobilizing and stabilizing. Most muscles in the body comprise both these elements, but it is possible to consider some muscles to be predominantly mobilizers and others to be predominantly stabilizers. This classification is not only functional, but histological and neurological as well. Histologically, mobilizing muscles have a high concentration of white muscle fibres, stabilizers having more red. Mobilizing muscles are usually fusiform in shape, they cross two or more joints and belong generally to the flexor and adductor groups. They tend to perform light work with the distal part of the limb free. Rectus femoris falls into this category. Stabilizers are commonly bipennate or irregular in shape, they cross one joint and are found to be extensors and abductors. Their action is to move the body over the fixed limb i.e. heavy work. The other components of quadriceps are stabilizers. The muscle spindles of single joint extensors are richly supplied with secondary afferents whose activity facilitates a co-contraction. (21) The nerve supply is thus also functionally arranged.
It is not only the peripheral innervation which is functionally orientated, but the central nervous system as well. Buchwald (7) states that "Central mechanisms upon which postural maintenance is primarily dependent would seem to reside in those pathways terminating most densely around the axial and extensor interneurons and motoneurons i.e. the vestibulospinal and reticulospinal tracts . . . Central control of limb movements and actions of fine co-ordination would seem to descend through those pathways terminating most heavily around the interneurons and motoneurons innervating the distal and flexor musculature i.e. pyramidal and rubrospinal tracts." p. 150.

It would seem then that in order to obtain the optimum response from any muscle group, irrespective of the specific movement technique employed, one must take into account its physiological function as well as its anatomical action.

To return to the quadriceps-this is a bi-functional muscle. The rectus femoris part is a mobilizer working principally with the light lever i.e. straight leg raising, while the other three components are stabilizers whose principal function is to move the body weight. Now, we have the patient with a reflex inhibition of the quadriceps, a splinted straight knee and he is not allowed to weight-bear. Before he is able to lift his leg (a co-ordinate pattern or skilled function) the patient must regain the stabilizing function of the quadriceps. If one attempts re-education without considering the functional level of the patient, therapy, if not completely unsuccessful, is certainly greatly hindered. One must thus as far as possible simulate weight-bearing conditions without putting any strain on the joint. This is not as difficult as it sounds. Stretch of the interosseus muscles of the foot has a facilitating effect on the postural muscles of the lower limb. Joint compression is facilitatory to extensor muscles. If a quick, alternate rotation of the hip in a very small range, is applied together with other superimposed facilitatory methods, a co-contraction of the muscle groups of the lower limb is elicited and the quadriceps contracts as a stabilizer. Stretch by gravity can be superimposed by placing the patient in the prone position. Once the quadriceps is able to function as a stabilizer, one can progress to using it in a coordinate pattern i.e. straight leg raising:

Effective re-education of quadriceps function is most difficult in the immediate post-operative stage. Once movement of the knee and weight-bearing are allowed, the problems are fewer. Normal function need not be simulated. The limb can be subjected to the natural facilitatory effects of changes in the centre of gravity, weight-bearing, walking, etc. as an essential part of the re-education program.

The action of the quadriceps is extremely complex and many aspects must be taken into consideration by the therapist solthat she can provide the most favourable conditions for rehabilitation. From experience it has been found that the application of a functional, developmental approach to rehabilitation can dynamically influence the musculoskeletal system.

\section{REFERENCES}

1. Barnett, C. H.: Locking at the knee joint. J. Anat. 87: $91-95,1953$.

2. Basmajian, J. V.: Grant's Method of Anatomy, 8th ed. Baltimore, Williams \& Wilkins, 1971.

3. Basmajian, J. V.: Muscles Alive, 2nd ed. Baltimore, Williams \& Wilkins, 1967.

4. Basmajian, J. V., Harden, T. P. \& Regenos, E. M.: Integrated actions of the four heads of quadriceps femors: An electromyographic study. Anat. Rec. 172: 15-20, 1972.

5. Brunnstrom, S.: Clinical kinesiology, 3rd ed. rev. by Dickinson, R. Philadelphia, F. A. Davis, 1972.

6. Buchwald, J. S.: Proprioceptive Reflexes and Posture. Am. J. Phys. Med. 46: 104-113, 1967.

7. Buchwald, J. S.: A functional concept of motor control. Am. J. Phys. Med. 46: 141-150, 1967.

8. Carlsöo, S. \& Nordstrand, A.: The co-ordination of the knee muscles in some voluntary movements and in the 
gait in cases with and without knee joint injuries. Acta Chir. Scand. 134: 423-426, 1968.

9. De Andrade, J. R., Grant, C. \& Dixon, A. St. J.: Joint distension and reflex muscle inhibition in the knee. $J$. Bone Joint Surg. 47A: 313-322, 1965.

10. Gardner, E., Gray, D. J. \& O'Rahilly, R.: Anatomy, 3rd ed. Philadelphia, W. B. Saunders, 1969.

11. Gray's Anatomy -ed. Warwick, R. \& Williams, P. L., 35th ed. Edinburgh, Longman, 1973.

12. Hall, M. C.: The Locomotor System: Functional Anatomy. Springfield, Charles C. Thomas, 1965.

13. Hallén, L. G. \& Lindahl, O.: Rotation in the knee joint in experimental injury to the ligaments. Acta Orthop. Scand. 36: 400-407, 1965.

14. Hallén, L. G. \& Lindahl, O.: The 'screw-home' movement in the knee joint. Acta Orthop. Scand. 37: 97-106, 1966.

15. Hallén, L. G. \& Lindahl, O.: Muscle function in knee extension: an electromyographic study. Acta Orthop. Scand. 38: 434-444, 1967.

16. Licht, S., ed.: Therapeutic Exercise, 2nd ed. rev. Baltimore, Licht, E., 1965.

17. Lieb, F. J. \& Perry, J.: Quadriceps function : an anatomical and mechanical study using amputated limbs. J. Bone Joint Surg. 50A: 1535-1548, 1968.

18. Lieb, F. J. \& Perry, J.: Quadriceps function: An electromyographic study under isometric conditions. J. Bone Joint Surg. 53A. No. 4: 749-758, 1971.

19. Lindahl, O. \& Movin, A.: The mechanics of extension of the knee joint. Acta Orthop. Scand. 38: 226-234, 1967.

20. MacConaill, M. A. \& Basmajian, J. V.: Muscles \& Movements. Baltimore, Williams \& Wilkins, 1969.

21. O'Connell, A. L. \& Gardner, E. B.: Understanding the Scientific Bases of Human Movement. Baltimore, Williams \& Wilkins, 1972.
Fully equipped Physiotherapy Practice for sale at coastal resort.

Easy, comfortable living as is or scope for enlargement.

\section{Enquiries:}

P.O. Box 11151, JOHANNESBURG.
22. Palmer, I.: Pathophysiology of the medical ligament the knee joint. Acta Chir. Scand. 115: 312-318, 1958 of

23. Petersén, I. \& Stener, B.: Experimental evaluation of the hypothesis of ligamento-muscular protective reflexes III A Study in man using the medial collateral ligames. of the knee. Acta Physiol. Scand. 48 Supp. 166, 1959.

24. Pocock, G. S.: Electromyographic study of the quadriceps during resistive exercise. J. Amer. Phys. Ther.
Assoc. 43: 427-434, 1963 .

25. Rasch, P. J. \& Burke, R. K.: Kinesiology and applies anatomy, 4th ed. Philadelphia, Lea \& Febiger, 1971 . 26. Steindler, A.: Kinesiology of the human body. Springfield,
Charles C. Thomas, 1955 .

27. Stener, B. \& Petersén, I. : Electromyographic investiga tion of reflex effects upon stretching the partially ruptured medial collateral ligament of the knee joint. Acta Chir. Scand. 124: 396-411, 1962.

28. Stener, B.: Reflex inhibition of the quadriceps elicited from a subperiosteal tumour of the femur. Acta Orthop. Scand. 40: 86-91, 1969.

29. Stockmeyer, S. A.: An interpretation of the approach $0_{1}$ Rood to the treatment of neuromuscular dysfunction. Am. J. Phys. Med. 46: 900-956, 1967.

30. Swearingen, R. L. \& Dehne, E.: A study of pathological muscle function following injury to a joint. J. Bone Joint Surg. 46A: 1364, Sept. 1964 (Proceedings).

31. Tokizane, T. \& Shimazu, H.: Functional differentiation of human skeletal muscle. Tokyo, University of Tokyo press, 1964.

32. Wells, K. F.: Kinesiology, 5th ed. Philadelphia, W. B. Saunders, 1971

33. Williams, M. \& Lissner, H. R.: Biomechanics of human motion. Philadelphia, W. B. Saunders, 1962.

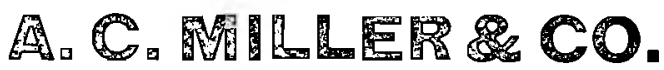 ORTHOPAEDIC MECHANICIANS}

Technicians registered with S.A. Medical and Dental Council specialising in the following: ORTHOPAEDIC APPLIANCES, SURGICAL CORSETS, CERVICAL COLLARS, CHILDREN'S SHOES AND BOOTS; ARTIFICIAL LIMBS, LATEST IN PLASTIC MODIFICATION. HIRING AND SELLING OF HOSPITAL EQUIPMENT AND SICK ROOM REQUISITES, e.g. WHEEL CHAIRS, COMMODES, HOSPITAL BEDS, WALKING AIDS, TRACTION APPARATUS, etc.

Telephone

P.O. Box 3412 23-2496 275 Bree Street 